\title{
DISKURSUS PEMBATASAN KEKUASAAN PRESIDEN DALAM SISTEM PRESIDENSIAL MENURUT UUD 1945
}

\author{
Abdul Rahman Kanang \\ Fakultas Syariah dan Hukum Universitas Islam Negeri Alauddin Makassar
}

\begin{abstract}
The presidential system adopted by Indonesian ideals gives broad powers to the president to carry out his executive duties. Such power cannot be limited or reduced without constitutional reasons. However, this great power cannot be used arbitrarily for his personal interests. Two constitutional restrictions that can be used as a basis for limiting the executive power of the president include the limitations of prerogative rights.
\end{abstract}

Keywords:

Limitation of Power, President, Presidential System

\begin{abstract}
Abstrak
Sistem presidensial yang dianut oleh Indonesia idealnya memberikan kekuasaan yang luas bagi presiden untuk melaksakan tugas-tugas eksekutifnya. Kekuasaan tersebut tidak dapat dibatasi atau dikurangi tanpa alasan yang bersifat konstitusional. Namun demikian, kekuasaan yang besar tersebut juga tidak dapat digunakan secara semena-mena untuk kepentingan pribadinya. Dua batasan konstitusional yang dapat dijadikan landasan serta dapat dijadikan alasan untuk membatasi kekuasaan eksekutif presiden antara lain adalah batasan hak prerogatif.
\end{abstract}

Kata Kunci:

Pembatasan Kekuasaan, Presiden, Sistem Presidensial

\section{A. PENDAHULUAN}

S istem pemerintahan yang dianut oleh Indonesia adalah sistem pemerintahan presidensial. ${ }^{1}$ Dapat dikatakan bahwa inilah Bab UUD 1945 yang paling banyak materi yang diatur di dalamnya, yaitu mulai dari Pasal 4 sampai dengan Pasal 16. Bahkan, ketentuan Bab V tentang Kementerian Negara yang terdiri atas Pasal 17, sebenarnya juga mengatur ketentuan mengenai pemerintahan negara di bawah

1 Lihat ketentuan Pasal 4 ayat (1) Undang-Undang Dasar 1945 yang menyatakan bahwa "Presiden Republik Indonesia memegang kekuasaan pemerintahan menurut Undang-Undang Dasar". Selain hal tersebut, kekuasaan pemerintahan negara oleh presiden juga diatur dalam Bab III UUD 1945 yang berisi 17 pasal yang mengatur berbagai aspek mengenai presiden dan lembaga kepresidenan, serta kewenangan yang dimilikinya dalam memegang kekuasaan pemerintah. 
tanggungjawab presiden dan wakil presiden. Malah, Bab VI tentang Pemerintah Daerah yang berisi Pasal 18, Pasal 18A, dan Pasal 18B, dapat pula disebut termasuk domain pemerintahan eksekutif. ${ }^{2}$

Penguatan sistem pemerintahan presidensial menjadi salah satu isu yang paling penting ketika pembahasan amandemen ke-dua UUD 1945. Sebetulnya sempat terjadi perdebatan alot yang diwarnai adanya perbedaan pendapat khususnya mengenai isu bentuk negara kesatuan dan sistem pemerintahan presidensial, para perumus amandemen UUD 1945 saat itu akhirnya menyepakati dipertahankannya bentuk negara kesatuan dan sistem pemerintahan presidensial. ${ }^{3}$ Adnan Buyung Nasution menyatakan bahwa setidaknya ada beberapa alasan sehingga terjadi kesepakatan mengenai tiga isu penting untuk tidak mengubah pembukaan UUD 1945. Hal ini untuk menghindari perdebatan yang tidak terselesaikan di era Konstituante 1956-1959 mengenai negara Pancasila atau negara Islam, dimana rumusan Pancasila yang menjadi dasar negara Indonesia tercantum dalam pembukaan UUD 1945. ${ }^{4}$ Ketidakstabilan situasi politik pada saat Indonesia menganut sistem pemerintahan parlementer pada tahun 1950 menyebabkan sistem pemerintahan presidensial dianggap menjadi pilihan yang tepat. Sedangkan sejarah kegagalan negara federal yang berlangsung pada tahun 1949 juga membawa kontribusi terhadap kesepakatan untuk mempertahankan bentuk negara kesatuan. ${ }^{5}$

Menurut Jimly Asshiddiqie, bahwa sistem peralementer pada masanya pernah gagal dipraktekkan dalam sejarah Indonesia, dan karenanya membuat sistem tersebut tidak populer di masyarakat. Sistem pemerintahan presidensial dianggap lebih menjamin stabilitas pemerintahan. Sistem presidensial juga tetap dapat dipraktekan bersama dengan sistem multi partai yang dapat mengakomodasi peta konfigurasi kekuatan politik dalam masyarakat dengan masyarakat Indonesia yang sangat kompleks dan beragam. ${ }^{6}$

Setelah amandemen UUD 1945, Indonesia dinyatakan menganut sistem presidensial yang bersifat konvensional. Sistem presidensial dikatan sebagai sistem konvensional apabila sejalan dengan karakteristik utama sebagai berikut: (i) terdiri dari seorang pimpinan eksekutif tunggal; (ii) pimpinan eksekutif tersebut dipilih langsung oleh rakyat; dan (iii) masa tugasnya dibatasi dan tidak dapat diberhentikan melalui pemungutan suara oleh lembaga legislatif. Sedangkan Sartori

2 Jimly Asshiddiqie, Perkembangan dan Konsolidasi Lembaga Negara Pasca Reformasi, Penerbit Sekretariat Jenderal Mahkamah Konstitusi RI, Jakarata, 2006, h. 117-118.

3 Denny Indrayana, Indonesian Constitutional Reform 1999-2000, An Evaluation of Constitutional Making in Transition (Jakarta: Kompas Book Publishing, 2008), h. 54.

${ }^{4}$ Adnan Buyung dikutip Denny Indrayana, Indonesian Constitutional Reform 1999-2000, An Evaluation of Constitutional Making in Transition, h. 121.

5 Denny Indrayana, Indonesian Constitutional Reform 1999-2000, An Evaluation of Constitutional Making in Transition, h. 121.

${ }_{6}^{6}$ Jimly Asshiddiqie, Struktur Ketatanegaraan Indonesia Setelah Perubahan Keempat UUD Tahun 1945 makalah disampaikan pada Seminar Pembangunan Hukum Nasional VIII yang diselenggarakan oleh Badan Pembinaan Pembangunan Hukum Nasional Departemen Hukum dan HAM pada tanggal 14-18 Juli 2003, h. 8. 
mengemukakan bahwa suatu negara dinyatakan menganut sistem presidensial apabila presidennya (i) dipilih langsung melalui popular election, (ii) tidak dapat diberhentikan oleh lembaga legislatif pada kurun waktu masa tugasnya, dan (iii) memimpin pemerintahan oleh orang-orang yang dia tunjuk. ${ }^{7}$

Meskipun Indonesia menganut system presidensial dan presiden telah dipilih langsung oleh rakyat, namun tidak serta merta membuat kekuasaannya menjadi tidak tak terbatas. Beberapa ketentuan dalam UUD 1945, baik tersurat maupun tersirat menunjukkan adanya pembatasan kekuasaan pemerintahan (Presiden). Sebagai contoh, presiden dapat diberhentikan dalam masa jabatannya oleh Majelis Permusyawaratan Rakyat atas usul Dewan Perwakilan Rakyat, baik apabila terbukti telah melakukan pelanggaran hukum berupa pengkhianatan terhadap negara, korupsi, penyuapan, tindak pidana berat lainnya, atau perbuatan tercela maupun apabila terbukti tidak lagi memenuhi syarat sebagai Presiden. ${ }^{8}$ Sedangkan dalam hubungannya dengan lembaga negara lain, diatur juga secara tegas bahwa Presiden tidak dapat membekukan dan/atau membubarkan Dewan Perwakilan Rakyat. ${ }^{9}$

Pembatasan kekuasaan Presiden dalam UUD 1945 juga dapat dilihat pada Pasal 20 ayat (2) sampai ayat (5) yang mengatur tentang peran serta Presiden dalam pembentukan undang-undang. Meskipun kekuasaan pembentukan undang-undang merupakan wilayah lembaga legislatif/DPR, namun Presiden tetap mendapatkan peran yang sangat penting karena menurut Pasal 20 tersebut bahwa setiap rancangan undang-undang dibahas oleh Dewan Perwakilan Rakyat dan Presiden untuk mendapat persetujuan bersama. ${ }^{10}$ Selanjutnya Presiden mengesahkan rancangan undang-undang yang telah disetujui bersama untuk menjadi undang-undang. Namun demikian, dalam hal rancangan undang-undang yang telah disetujui bersama tersebut tidak disahkan oleh Presiden dalam waktu tiga puluh hari semenjak rancangan undang-undang tersebut disetujui, rancangan undang-undang tersebut sah menjadi undang-undang dan wajib diundangkan. ${ }^{11}$

Presiden di Indonesia yang masih memiliki peran dalam pembahasan undangundang yang merupakan ranah kekuasaan legislative, memang berbeda dengan negara yang menganut sistem presidensial murni seperti misalnya Amerika Serikat. ${ }^{12}$ Presiden di Amerika Serikat tidak memiliki peran dalam pembahasan rancangan undang-undang, namun diberikan hak veto untuk menolak mengesahkan rancangan undang-undang hasil pembahasan lembaga legislatif. ${ }^{13}$ Hak veto tersebut diberikan oleh konstitusi Amerika Serikat kepada presiden sebagai bentuk check and balances

${ }^{7}$ Arendt Lijphart dan Giovanni Sartori dikutip Denny Indrayana, Indonesian Constitutional Reform 19992000, An Evaluation of Constitutional Making in Transition, h. 279-279.

${ }^{8}$ Pasal 7A UUD 1945.

${ }^{9}$ Pasal 7C UUD 1945.

${ }^{10}$ Pasal 20 ayat (2) UUD 1945.

${ }^{11}$ Pasal 20 ayat (1), ayat (2), ayat (3), ayat (4) dan ayat (5) UUD 1945.

12 Denny Indrayana, Indonesian Constitutional Reform 1999-2000, An Evaluation of Constitutional Making in Transition, h. 121.

${ }^{13}$ Article I section 7 of the US Constituion. 
antar lembaga negara, khususnya untuk mencegah tirani mayoritas di lembaga legislatif yang memungkinkan akan mengeluarkan undang-undang yang merugikan masyarakat. ${ }^{14}$ Hak veto presiden sendiri telah disepakati secara luas bukan sebagai bentuk kekuasaan legislatif presiden, namun hanyalah merupakan alat formal untuk mempengaruhi kekuasaan pembentukan undang-undang lembaga legislatif. ${ }^{15}$

Menurut Denny Indrayana, tidak adanya kewenangan presiden untuk menolak mengesahkan rancangan undang-undang dari DPR tidak berarti bahwa Presiden di Indonesia tidak memiliki hak veto. UUD 1945 telah menatur bahwa setiap rancangan undang-undang dibahas oleh Dewan Perwakilan Rakyat dan Presiden untuk mendapat persetujuan bersama. ${ }^{16}$ Persetujuan Presiden dalam ketentuan tersebut pada dasarnya adalah hak veto. Namun begitu, jika persetujuan telah diberikan oleh presiden, maka Presiden tidak dapat menolak untuk mengesahkan rancangan undang-undang tersebut menjadi undang-undang. ${ }^{17}$

Dalam hal pengesahan rancangan undang-undang, sekalipun presiden tidak mau menandatangani rangangan undang-undang yang telah disetujui bersama, rancangan undang-undang tersebut otomatis menjadi undang-undang setelah 30 hari semenjak disetujui bersama. ${ }^{18}$ Batasan kekuasaan eksekutif presiden selanjutnya adalah Presiden berhak mengangkat duta dan konsul. Namun kewenangan tersebut tidaklah mutlak karena dalam mengangkat duta dan konsul ${ }^{19}$ serta memberikan amnesti dan abolisi, presiden harus memperhatikan pertimbangan DPR. ${ }^{20}$ Presiden memiliki hak untuk memberi grasi dan rehabilitasi namun dengan memperhatikan pertimbangan Mahkamah Agung.

Beberapa contoh tersebut di atas, meskipun sudah ada batasan yang cukup rinci dalam UUD 1945 mengenai batas-batas kewenangan eksekutif presiden, tetapi masih terdapat beberapa permasalahan. ${ }^{21}$ Demikian pula halnya mengenai pro-kontra pengangkatan Kepala Kepolisian RI (Kapolri) yang berujung pada uji materiil di Mahkamah Konstitusi terhadap UU No. 2 Tahun 2002 tentang Kepolisian RI dan UU No. 34 Tahun 2004 tentang Tentara Republik Indoenesia.

Undang-undang tersebut dianggap membatasi kekuasaan presiden untuk mengangkat dan memberhentikan Kapolri serta Panglima TNI karena harus dilakukan dengan persetujuan DPR. Berbeda dengan batasan kekuasaan eksekutif lainnya yang secara tegas dituangkan dalam UUD 1945, yaitu batas kekuasaan

14 Ladasan historis hak veto Presiden di Amerika Serikat dapat ditelusuri misalnya dalam tulisan Alexander Hamilton dalam the Federalist No. 73.

15 Jasmin Farrier, Legislatif Leader dalam The Powers of the Presidency (4th Edition), CQ Press, Los Angeles California, 2013, hlm. 149.

${ }^{16}$ Pasal 20 ayat (2) UUD 1945.

17 Denny Indrayana, Indonesian Constitutional Reform 1999-2000, An Evaluation of Constitutional Making in Transition, h. 169.

${ }^{18}$ Pasal 20 ayat (5) UUD 1945.

${ }^{19}$ Pasal 13 ayat (1) dan ayat (2)

${ }^{20}$ Pasal 14 ayat (1).

${ }^{21}$ Hendra Wahanu Prabandani, Batasan Konstitusional Kekuasaan Eksekutif Presiden: Constitutional Limits Of The Presidential Executive Power (Jakarta: Jurnal Legislasi, 2015), h. 6. 
presiden pada saat akan memilih Kapolri dan Panglima TNI hanya dirumuskan dalam undang-undang yang merupakan produk lembaga legislatif. Menurut Hendra Wahanu Prabandani, timbulnya permasalahan mengenai batas kekuasaan eksekutif presiden tersebut secara konsepsi ketatanegaraan tidak dapat dipandang sebagai hal yang sederhana. ${ }^{22}$ Misalnya dalam hal kewenangan pengangkatan Kapolri dan Panglima TNI, pembatasan kekuasaan presiden dapat dimaknai sebagai saling intervensi cabang kekuasaan negara. Hal ini dianggap menyalahi prinsip separation of powers dari teori trias politika ${ }^{23}$ karena DPR yang merupakan lembaga legislatif menggunakan kekuasaannya untuk membatasi kewenangan eksekutif presiden. Doktrin separation of powers atau pemisahan kekuasaan memang tidak dapat ditemukan secara tekstual dalam konstitusi, namun telah disepakati secara luas bahwa kedudukannya sangat mendasar dalam Negara demokrasi. Separation of powers merupakan fondasi yang membentuk struktur konstitusi itu sendiri.

Pertanyaan yang muncul kemudian adalah apakah pembatasan masa jabatan presiden dengan serta merta dapat membatasi kekuasaan Presiden? yang pembatasan kekuasaan Presiden tersebut bukan hanya meliputi pembatasan masa jabatan Presiden, tetapi juga dapat meliputi isi kekuasaannya. ${ }^{24}$ Terkait dengan hal tersebut, tulisan ini bermaksud untuk menggali lebih lanjut mengenai batas-batas kekuasaan eksekutif presiden selain yang telah diatur dalam UUD 1945, khususnya terkait dengan pertanyaan apakah presiden memiliki hak prerogatif atau hak asli (inherent rights) yang melekat pada kekuasaannya dengan dan/atau tanpa diberikan secara tekstual oleh UUD 1945? Penelusuran mengenai batas-batas kekuasaan eksekutif presiden tersebut akan dilakukan melalui pendekatan sejarah (historical practices), teori konstitusi (constitutional theory) maupun perbandingannya dengan negara lain (legal comparison).

Terlepas dari polemik pembatasan kekuasaan presiden tersebut di atas, menurut hemat penulis, memang perlu pembatasan kekuasaan presiden dalam menjalankan wewenangnya sebab jika tidak, maka Presiden dapat menjalankan kekuasaannya secara absolut atau dapat bertindak secara tidak terbatas. Oleh karena itu sangat perlu ada mekanisme saling mengendalikan dan mengimbangi (checks and balances) antara cabang kekuasaan legislatif, yudikatif dan eksekutif.

22 Hendra Wahanu Prabandani, Batasan Konstitusional Kekuasaan Eksekutif Presiden: Constitutional Limits Of The Presidential Executive Power (Jakarta: Jurnal Legislasi, 2015), h. 7.

${ }^{23}$ Teori Montesquiew yang menginginkan adanya pembagian kekuasaan ke dalam tiga macam lembaga kekuasaan, yaitu kekuasaan eksekutif, kekuasaan legislative dan kekuasaan yudikatif.

${ }^{24}$ Sri Soemantri Martosoewignjo mengatakan bahwa pembatasan kekuasaan lembaga-lembaga negara meliputi dua hal, antara lain: Pertama, pembatasan kekuasaan yang meliputi isi kekuasaannya; dan Kedua, pembatasan kekuasaan yang berkenaan "waktu" dijalankannya kekuasaan tersebut. Lihat dalam Sri Soemantri M., Konstitusi Serta Artinya Untuk Negara, Padmo Wahjono (Editor), Masalah Ketatanegaraan Indonesia Dewasa Ini (Jakarta: Ghalia Indonesia, 1984), h. 10. 


\section{B. PEMBAHASAN}

\section{Makna Hak Prerogatif Presiden}

Istilah hak prerogatif sering kali dipergunakan baik oleh eksekutif, legislatif ataupun pengamat terhadap hak istimewa yang dimiliki presiden untuk menunjuk dan mengangkat orang-orang menjadi pembantunya (menteri-menteri). Namun, apabila ditelaah secara lebih mendalam tentang hak prerogatif tersebut dari sudut pandang hukum tata negara, maka hak prerogatif yang dipahami sebagai hak istimewa, utama dan mutlah tersebut, bisa jadi akan memperoleh kesimpulan yang berbeda.

Prerogatif berasal dari bahasa latin praerogativa ( dipilih sebagai yang paling dahulu memberi suara), praerogativus (diminta sebagai yang pertama memberi suara), praerogare (diminta sebelum meminta yang lain). ${ }^{25}$ Menurut Kamus Besar Bahasa Indonesia, prerogatif didefinisikan sebagai hak istimewa yang dipunyai oleh kepala negara mengenai hukum dan undang-undang di luar kekuasaan badanbadan perwakilan. ${ }^{26}$ Lebih lanjut disebutkan bahwa hak prerogatif adalah hak khusus atau hak istimewa yang ada pada seseorang karena kedudukannya sebagai kepala negara, seperti memberi tanda jasa, gelar, grasi, amnesti, dan lain-lain.

Dalam hukum Inggris, prerogatif merupakan sebuah kekuasaan atau kehendak yang memiliki sifat diskresi, dan yang tertinggi (di atas) dan tidak terkendali oleh kehendak lain. Dimana dikhususkan bagi keunggulan raja (atau ratu) yang lebih dari dan di atas semua orang lain, merupakan hak dan martabatnya yang agung. Sebuah istilah yang digunakan untuk menunjukkan hak-hak dan kapasitas yang berdaulat sendiri, bertentangan dengan orang lain." Definisi tersebut menunjukkan bahwa prerogatif merupakan hak istimewa bagi pemegang kekuasaan untuk menentukan sesuatu tanpa dapat diawasi atau dihilangkan oleh orang lain karena kedudukannya yang agung dan berdaulat. Dengan demikian prerogatif memiliki kecenderungan untuk disalah gunakan. Apabila dilihat dari sudut pandang pranata hukum khususnya hukum tata negara, prerogatif berasal dari sistem ketatanegaraan Inggris (United Kingdom). ${ }^{27}$ Menurut Dicey, hak prerogatif secara historis dan sebagai sebuah fakta aktual, tampaknya tidak lain hanyalah residu dari kewenangan diskresi yang dimiliki Ratu / Raja. ${ }^{28}$ Kewenangan diskresi Raja tersebut bukanlah berasal dari undang-undang yang dibentuk oleh parlemen, melainkan bersumber pada "common law" atau hukum tidak tertulis yang berasal dari putusan hakim. ${ }^{29}$

${ }^{25}$ Bagir Manan, Kekuasaan Prerogatif, Makalah yang dipublikasikan di Bandung, 20 Agustus 1998.

${ }^{26}$ Kementerian Pendidikan Nasional RI, Kamus Besar Bahasa Indonesia (Jakarta: Pusat Bahasa, 2012), h. 1212.

${ }^{27}$ Bagir Manan, Kekuasaan Prerogatif, h. 23.

28 A.V. Dicey, Introduction to the Study of the Law of the Constitution, Terjemahan oleh Nurhadi, Pengantar Studi Hukum Konstitusi (Bandung: Nusa Media, 2007), h. 454.

${ }^{29}$ Dicey dikutif Bagir Manan menyebutkan, setiap tindakan yang sah (legal) dilakukan oleh pemerintah eksekutif tanpa mendapatkannya berdasarkan undang-undang yang dibentuk oleh parlemen itu dilakukan dengan hak prerogatif ini. A.V. Dicey, h. 454. 
Dalam sejarah ketatanegaraan Inggris, kekuasaan (kewenangan) Raja sebenarnya ada terlebih dahulu dibandingkan kekuasaan parlemen (Majelis Rendah). Pergolakan yang terjadi di Inggris waktu itu, sebagai bentuk perlawanan atas kekuasaan mutlak Raja yang sewenang-wenang, menimbulkan sebuah Revolusi Tahun 1688, telah memaksa Raja untuk menyerahkan sebagian kekuasaannya tersebut kepada Majelis Rendah (House of Commons) yang mewakili rakyat. Sisa-sisa (residu) dari kekuasaan Raja tersebutlah yang kemudian disebut sebagai hak prerogatif. Menurut Dicey, hak prerogatif ini menjadi nama bagi residu kekuasaan bebas yang pada saat kapanpun tetap ada di tangan Raja, apakah kekuasaan tersebut dalam kenyataannya dijalankan oleh Raja itu sendiri atau oleh Menteri-Menterinya. ${ }^{30}$ Karena tidak berasal atau tidak ditentukan pada peraturan perundang-undangan yang dibuat oleh parlemen, maka kekuasaan prerogatif mengandung kekuasaan diskresi (discretionary power). ${ }^{31}$

Hak eksekutif diluar hak-hak yang telah diberikan kepada presiden oleh konstitusi menjadi hal yang sentral untuk dibahas. Misalnya dalam Pasal 17 ayat (2) UUD 1945 disebutkan bahwa menteri-menteri diangkat dan diberhentikan oleh presiden. hal ini berbeda dengan ketentuan tentang pengangkatan duta dan konsul yang harus melalui pertimbangan DPR. ${ }^{32}$ Pertanyaan yang muncul kemudian adalah apakah kekuasaan mengangkat menteri adalah hak prerogatif presiden, sedangkan pengakatan duta dan konsul bukanlah merupakan hak prerogatif presiden? Apakah untuk disebut hak prerogatif harus dinyatakan secara tegas dalam UUD 1945? Bagaimana misalnya dengan pengangkatan pejabat eksekutif lain tidak disebutkan dalam UUD 1945?. Terdapat beberapa perbedaan pandangan mengenai hal ini.

Saldi Isra mengutif pendapat Bagir Manan yang mengemukakan bahwa hak prerogatif merupakan hak presiden yang diberikan langsung oleh konstitusi. Contoh yang paling riil adalah hak presiden untuk mengangkat menteri sebagai pembantunya sebagaimana diatur dengan tegas dalam Pasal 17 UUD 1945. Namun berbeda pada saat presiden akan mengubah lembaga atau institusi kementerian negara, hal ini harus dilaksanakan dengan persetujuan DPR. ${ }^{33}$ Sehingga yang demikian bukanlah merupakan bagian dari hak prerogatif presiden.

Pendapat lain menyatakan bahwa hak yang dimiliki presiden sepanjang hak tersebut adalah konstitusional maka merupakan bagian dari kekuasaan eksekutif presiden. Pendapat ini tidak khusus menunjuk pada konsep yang disebut sebagai hak prerogatif namun lebih kepada hak yang dimiliki oleh presiden secara

${ }^{30}$ A.V. Dicey, A.V. Dicey, Introduction to the Study of the Law of the Constitution, h. 455.

${ }^{31}$ Bagir Manan menyebutkan bahwa prerogatif disebut sebagai "residu" karena kekuasaan ini tidak lain dari sisa seluruh kekuasaan yang semula ada pada Ratu/Raja Inggris (kekuasaan mutlak) yang kemudian makin berkurang karena beralih ketangan rakyat (parlemen) atau unsur-unsur pemerintah lainnya (seperti Menteri), h. 5 .

${ }^{32}$ Pasal 13 ayat (2) UUD 1945.

33 Pendapat ahli Saldi Isra dalam risalah sidang Mahkamah Konstitusi No. 22/PUU-XII/2015 perihal Pengujian UU No. 2 Tahun 2002 tentang Kepolisian RI dan UU No. 34 Tahun 2004 tentang TNI, tanggal 15 April 2015, h. 3-4. 
konstitusional. Hardjono ${ }^{34}$ menyatakan bahwa setiap hak yang dimiliki secara konstitusional oleh presiden merupakan hak eksekutif yang juga adalah hak prerogatif itu sendiri. Hardjono mengemukakan bahwa belum ada penjelasan mengenai apa sesungguhnya yang disebut sebagai hak prerogatif presiden tersebut.

Ada pendapat yang mengatakan bahwa hak prerogatif merupakan hak presiden untuk mengisi sesuatu yang tidak diatur dalam konstitusi. Menurut Zaenal Arifin Mochtar hak prerogatif ini mengisi sesuatu yang tidak diatur secara detail dalam konstitusi. Misalnya ketika Presiden menarik calon Kapolri yang sudah melalui seleksi di DPR. Bagi penganut ide ini, hal tersebut adalah bagian dari constitutional power karena tidak diatur di undang-undang mana pun, termasuk tidak diatur dalam Undang-Undang Kepolisian. ${ }^{35}$

Apabila ditelusuri dari sisi sejarah, pendapat terakhir yang menyatakan bahwa hak prerogatif merupakan constitutional power presiden untuk mengisi yang tidak diatur secara detail dalam konstitusi merupakan pendapat yang paling kuat. Hak ini tidak harus tertulis atau dinyatakan dalam teks konstitusi. Oleh karenanya, meskipun eksekutif dilengkapi dengan hak prerogatif namun penggunaan hak tersebut tidak dapat digunakan dengan sekehendak hatinya.

Hal yang masih perlu diperdalam dalam hal ini adalah apakah Presiden masih memiliki hak lain selain yang diberikan langsung oleh konstitusi? Ataukah mungkin presiden memiliki hak lain diluar konstitusi yang berarti bukan merupakan hak prerogatif?.

Selanjutnya, Clement Fatovic menyampaikan bahwa "prerogatif as an aberration from the normal operation of executive power. Whereas prerogative is a highly discretionary power that operates outside the bounds of the law, executive power is a rule-bound power that operates within the bounds of the law". ${ }^{36}$ Ide ini berarti juga tidak sejalan dengan konsep yang disampaikan oleh Hardjono yang menyatakan bahwa setiap hak yang dimiliki secara konstitusional oleh presiden merupakan hak eksekutif yang juga adalah hak prerogatif itu sendiri. Berdasarkan pendapat Clement Fatovic diatas, maka jelas terdapat perbedaan atas hak eksekutif dengan hak prerogatif. Hak eksekutif merupakan yang telah diatur secara hukum, sedangkan hak prerogatif dapat dijalankan meskipun tidak diatur secara tekstual oleh undang-undang.

Sejarah menunjukkan bahwa hak prerogatif pada awalnya adalah hak yang dimiliki oleh Raja Inggris (royal prerogatives) sebagai panglima angkatan bersenjata, hak untuk menolak rancangan peraturan (absolute veto), kewenangan penuh untuk mengangkat pejabat dan hakim, memberikan grasi dan amnesti, membuat perjanjian dengan negara lain, serta mengirim dan menerima duta serta pejabat kunci lainnya.

${ }^{34}$ Harjono adalah mantan hakim Mahkamah Konstitusi Republik Indonesia.

35 Pendapat ahli Hardjono dalam risalah sidang Mahkamah Konstitusi No. 22/PUU-XII/2015 perihal Pengujian UU No. 2 Tahun 2002 tentang Kepolisian RI dan UU No. 34 Tahun 2004 tentang TNI, tanggal 15 April 2015, h. 22.

${ }^{36}$ Clement Fatovic, Blurring The Lines: The Continuities Between Executive Power And Prerogative, Maryland Law Review, Vol. 73 No. 15, 2013, h. 15 
Perdebatan yang sampai saat ini masih belum selesai mengenai hak prerogative presiden, disebabkan karena Indonesia masih belum memiliki bangunan konseptual yang jelas mengenai hak prerogatif presiden sebagai bagian dari kekuasaan eksekutif presiden. Hal ini juga nampaknya luput dari bahasan para perumus perubahan UUD 1945. Denny Indrayana menyatakan bahwa para perumus perubahan UUD 1945 kurang mendalami mengenai mengapa dipilihnya sistem presidensial di Indonesia serta apa konsekuensinya terhadap kekuasaan presiden. Mengutif pendapat Andrew Ellis, Denny Indrayana mengemukakan bahwa:

"Yet no factions presented convincing reasons as to why the preamble, the unitary state and the presidential system should not be amended. PDIP, which was in favor of the preservation, was vague about its reasons. With regard to the preamble, the PDIP repeated the argument it had put in the First Amendment discussions, that the preamble contained the state philosophy, the Pancasila. This argument reaffirmed the nationalistsecular faction position, of rejecting an Islamic state. The PDIP's basic argument, in favor of the unitary state, was merely based on the third principle of the Pancasila of 'the unity of Indonesia'.As for maintaining the presidential system, the PDIP presented no supporting argument at all". ${ }^{37}$

Indonesia sebagai negara yang menganut sistem presidensial, pendekatan yang menyatakan bahwa hak prerogatif merupakan constitutional power presiden untuk mengisi ruang yang tidak diatur secara detail dalam konstitusi, nampaknya cocok untuk diterapkan di Indonesia karena pendapat ini didukung dari pengalaman sejarah (historical practices) maupun teori konstitusi. ${ }^{38}$ Meski demikian, pendapat John Locke yang menyampaikan bahwa constitutional power ini perlu dibatasi penggunaannya pada keadaan yang bersifat luar biasa sampai dengan lembaga legislatif dapat mengatur kondisi tersebut patut untuk menjadi perhatian. Hal ini penting dikarenakan penggunaan hak prerogatif yang tidak terbatas, secara nyata akan bertentangan dengan prinsip kepastian yang menjadi fondasi penting dalam negara hukum.

\section{Doktri Trias Politika.}

Adanya doktrin pembagian kekuasaan antar cabang pemerintahan merupakan bahasan yang penting bila dikaitkan dengan batas-batas kekuasaan eksekutif presiden. Ide besar dibalik separation of power yang dikemukakan oleh Baron de Montesquieu mengenai perlunya pembagian kekuasaan diantara cabang pemerintahan adalah untuk menghindari terjadinya satu kekuasaan yang absolut. Terkait dengan hal tersebut, John D Richard dengan mengutip pendapat Montesquieu menyatakan bahwa "firmly committed to the rule of law, Montesquieu

37 Denny Indrayana, Indonesian Constitutional Reform 1999-2000, An Evaluation of Constitutional Making in Transition, h. 144.

${ }^{38}$ Hendra Wahanu Prabandani, Batasan Konstitusional Kekuasaan Eksekutif Presiden: Constitutional Limits Of The Presidential Executive Power, h. 13. 
believed that the division of the state's powers into distinct spheres of legislatif, executive, and judicial authority would prevent tyranny... [h] advocated that allowing each branch to check the powers of the other two branches would ensure compliance with the rule of law. Therefore, no individual branch of government could threaten the freedom" ${ }^{\prime 3}$.

Menurut doktrin trias politika, cabang kekuasaan eksekutif, legislative dan yudikatif harus dipisahkan secara tegas. Masing-masing cabang akan memiliki personilnya sendiri dan tidak memungkinkan adanya percampuran fungsi diantara ketiganya. Tujuan pemisahan tersebut antara lain adalah menjalankan fungsi kontrol, menjaga keamanan dan menjalankan pemerintahan negara. ${ }^{40}$

\section{Konsep Check and Balances.}

Konsep check and balances berasal dari teori klasik tentang mixed atau balanced government yang dipraktekkan di Inggris. Mixed government tidak mendasarkan pada pembagian kekuasaan, akan tetapi lebih menekankan pada pentingnya partisipasi dari kelompok/kelas sosial yang ada dalam masyarakat saat itu. Keiga kelas sosial di Inggris yaitu raja, para tuan tanah (lord), dan kelompok yang mewakili mayoritas masyarakat (commons) harus terlibat dalam penyusunan undang-undang sehingga tidak ada satu kelompok yang dapat memaksakan kehendaknya.

Praktek ketatanegaraan modern saat ini, termasuk Indonesia, meunjukkan bahwa berbagai negara melaksanakan percampuran antara doktrin separation of powers dan check and balances dalam satu paket. Sebagai contoh nampak dalam UUD 1945 dimana secara jelas membagi kekuasaan dalam tiga cabang yaitu eksekutif, legislatif dan yudikatif. Selanjutnya mengalokasikan ke-tiganya dalam tiga lembaga yang terpisah dengan personil yang juga saling terpisah satu dengan lainnya. Sedangkan implementasi check and balances tidak dinampakkan dengan partisipasi tiga kelas sosial namun dilakukan oleh tiga cabang kekuasaan tersebut. Begitupun yang terjadi di Amerika Serikat, dimana representasi check and balances dalam konstitusi Amerika Serikat nampak dalam pengaturan tentang dibatasinya hak veto presiden, ketentuan tentang consent dan advice dari senat, serta proses impeachment baik bagi eksekutif maupun bagi hakim sebagai aktor pemegang kekuasaan legislatif. ${ }^{41}$

Demikian halnya dengan yang dipraktekkan di Negara-negara bekas koloni Inggris seperti Canada. John D Richard mengemukakan bahwa Canada tidak mempraktekkan doktrin separation of powers secara ketat, dan sekaligus juga mengenal check and balances dalam konstitusi mereka. ${ }^{42}$ Check balances dipraktekkan

\footnotetext{
${ }^{39}$ John D. Richard, Separation of Powers: The Canadian Experience, Duquesne Law Review, Vol. 47 No. 731, 209, h. 741.

${ }^{40}$ M. Elizabeth Magill, The Real Separation in Separation of Powers Law, Virginia Law Review, Vol. 86 No. 1127, h. 1163-1164

${ }^{41}$ M. Elizabeth Magill, The Real Separation in Separation of Powers Law, Virginia Law Review, h. 11651166.

${ }^{42}$ M. Elizabeth Magill, The Real Separation in Separation of Powers Law, Virginia Law Review, h. 759.
} 
antara lain dengan dikenalnya mekanisme review pengadilan atas kebijakan pemerintah maupun undnag-undang yang dihasilkan oleh lembaga legislatif.

UUD 1945 juga mengakui percampuran antara doktrin separation of powers dengan check and balances. Hal ini secara eksplisit terlihat dalam UUD 1945 yang secara jelas membedakan antara kekuasaan pemerintahan (eksekutif), kekuasaan membentuk undang-undang (legislatif), serta kekuasaan kehakiman (yudikatif) serta mengalokasikan kekuasaan tersebut masing-masing dalam suatu lembaga khusus. Selain itu dikenal juga doktrin check and balances diantara cabang kekuasaan misalnya melalui mekanisme pembahasan bersama undang-undang, persetujuan DPR dalam pemilihan duta dan konsul, mekanisme judicial review oleh mahkamah agung dan mahkamah konstitusi, dan lain-lain.

Persoalan mengenai batas kekuasaan eksekutif presiden akhirnya berkaitan dengan dengan implementasi dari dua doktrin ketatanegaraan tersebut. Diskursus ketatanegaraan dewasa ini lebih mengarah kepada sejauhmana masing-masing cabang kekuasaan tersebut dapat melakukan check terhadap cabang kekuasaan lainya dalam rangka menciptakan balancing kekuasaan. Dalam hal permasalahan yang lebih relevan misalnya adalah sejauh mana presiden dapat menjalankan kekuasaan eksekutifnya dan seberapa kuat lembaga lain diperbolehkan untuk membatasi penggunaan kekuasaan tersebut. Hal ini tidak menjadi persolan misalnya pada saat presiden mengangkat menteri yang secara tegas telah diatur dalam UUD 1945 sebagai kewenangan presiden, atau pada saat mengangkat duta dan konsul yang harus dilakukan dengan persetujuan DPR. ${ }^{43}$

Persoalannya kemudian adalah, bagaimana halnya ketika DPR membuat undang-undang yang mewajibkan presiden untuk mendapat persetujuan DPR pada saat mengangkat pejabat eksekutif seperti Kepala Kepolisian RI atau Panglima TNI. Mengenai hal ini, terdapat dua pandangan mengenai derajat deviasi dalam implementasi doktrin separation of powers yaitu pendekatan formalist dan pendekatan functionalist.

Functionalism mengutamakan pada pencapaian tujuan dari konstitusi, sedangkan formalism fokus pada teks konstitusi dan maksud para pendiri bangsa saat menyusun konstitusi. ${ }^{44}$ Penganut paham formalis memandang bahwa doktrin separation of powers membagi dengan tegas fungsi eksekutif, legislatif dan yudikatif. Dalam hal ini tidak memungkinkan adanya saling mempengaruhi antar cabang kekuasaan pemerintahan.

Sedangkan fungsionalis beranggapan bahwa setiap cabang kekuasaan memiliki fungsi-fungsi pokok (core functions) yang tidak dapat dikurangi, namun diluar hal tersebut kemungkinan adanya pengaruh dari cabang kekuasaan lain tidak dianggap bertentangan dengan separation of powers. Pengaruh antar cabang kekuasaan harus

\footnotetext{
${ }^{43}$ Pasal 13 UUD 1945.

44 John F. Manning, Separation Of Powers As Ordinary Interpretation, Harvard Law Review, Vol 124 No. 1939, 2011, h.1949.
} 
diukur mengguankan standar yang merupakan karakteristik doktrin separation of powers yaitu: (i) mempertahankan sistem check and balances; (ii) mencegah konsentrasi kekuasaan pada satu cabang pemerintahan; (iii) melindungi hak-hak individu warga negara; dan (iv) memungkinkan pelaksanaan check and balances serta kerjasama antar cabang kekuasaan untuk mencapai pemerintahan yang efektif. ${ }^{45}$

Kedua pendekatan tersebut sama-sama memiliki kelebihan dan kekurangan. Formalis seringkali mengkritik fungsionalis sebagai pihak yang tidak konsisten dengan struktur teks maupun dengan maksud dari para perumus konstitusi. Selain hal tersebut, formalis menganggap pendekatan fungtionalis bersifat terlalu ad hoc dan tidak konsisten dengan prinsip negara hukum. Sebaliknya, para penganut paham fungsionalis beranggapan bahwa pendekatan formalis bersifat anti-historis, kaku dan sudah cocoklagi diterapkan di era Negara modern. Manakalah kedua teori tersebut diaplikasikan pada kasus mengenai ketentuan tentang persetujuan DPR dalam pemilihan Kepala Kepolisian RI dan Panglima TNI yang berada di wilayah kekusaaan eksekutif, maka akan dapat diprediksi hasil analisanya.

Analisis dengan menggunakan pendekatan formalis akan menyimpulkan bahwa batasan yang dibuat oleh DPR melalui undang-undang melanggar prinsip separation of powers oleh kekuasaan legislatif terhadap eksekutif. Hal tersebut dikarenakan tidak adanya ketentuan dalam teks konstitusi yang mengatur bahwa Presiden harus mendapatkan persetujuan DPR pada saat akan mengangkat Kapolri dan tidak ditemukannya pembahasan mengenai hal tersebut pada saat perumusan UUD 1945. Pandangan ini juga didukung oleh the unitary executive doctrine yang menyatakan bahwa presiden adalah satu-satunya pemegang kekuasaan eksekutif termasuk kekuasaan dalam mengangkat dan memberhentikan pejabat eksekutif yang berada dibawahnya. Sebaliknya, analisis fungtionalis akan menyampaikan pendapat yang berbeda dan menyatakan batasan terhadap kekuasaan presiden tersebut adalah konstitusional.

Pandangan fungsionalis berpendapat bahwa selama kualifikasi tersebut tidak memberikan dampak yang mendasar terhadap presiden untuk menjalankan kekuasaan eksekutifnya maka pengaruh DPR kepada presiden tersebut diijinkan secara konstitusi. Batasan kewenangan presiden tersebut mungkin juga dapat dianggap sebagai bentuk check and balances diantara lembaga negara. Tentu saja ada kemungkinan dimana pendekatan formalis dan fungsionalis akan membawa hasil yang sama, terutama pada area dimana jabatan tersebut sangat penting bagi pelaksanaan fungsi kepresidenan atau eksekutif.

Apabila DPR mewajibkan presiden untuk mendapatkan persetujuan dari DPR pada saat akan mengangkat pejabat tersebut, maka hal tersebut jelas melanggar prinsip separation of powers baik dari pendekatan formalis maupun fungsionalis. Hal ini dikarenakan pembatasan tersebut secara nyata merupakan bentuk intervensi

45 Jesse H.Choper et all sebagaimana dikutif oleh Hendra Wahanu Prabandani, Batasan Konstitusional Kekuasaan Eksekutif Presiden: Constitutional Limits Of The Presidential Executive Power, h. 274 
lembaga legislatif terhadap keukasaan eksekutif sekaligus akan sangat mengganggu presiden untuk menjalankan fungsi eksekutifnya. ${ }^{46}$

Untuk menilai konstitusionalitas tindakan tersebut, Erwin Chemerinsky mengemukakan bahwa alasan tidak konsistennya pertimbangan Mahkamah Agung Amerika Serikat pada saat memutuskan perkara yang berkaitan dengan doktrin separation of powers masih belum jelas. Para ahli hukum tata Negara hanya dapat menduga bahwa setiap hakim memiliki ideologi yang dianutnya sendiri yang akan mempengaruhi pada saat melakukan analisa terkait permasalahan tersebut. Pada saat mayoritas hakim yang duduk di Mahkamah Agung memiliki pandangan yang bersifat formalism maka kecenderungan perkara tersebut akan akan diputuskan dengan pendekatan formalistik, begitupun sebaliknya. Namun demikian, pandangan tersebut ternyata juga tidak selalu benar karena ada masa dimana para hakim tersebut mencoba menghindari dikotomi analisis formalis dan fungsionalis dalam memutuskan perkara mengenai separation of powers. Hal terebut nampak misalnya pada saat mereka menggunakan analisis sederhana dengan hanya mendasarkan pada pembacaan dangkal atas teks konstitusi. ${ }^{47}$

Indonesia yang masih dalam proses membangun fondasi negara hukum dan demokrasi masih terus mencari formulasi terbaik pada saat menghadapi permasalahan-permasalahan ketatanegaraan kontemporer semacam ini. Oleh karena itu peran Mahkamah Konstitusi sangat urgen untuk menentukan bagaimana tafsir terhadap ide-ide dasar yang terkandung dalam UUD 1945. Kasus terkait kewajiban untuk mendapatkan persetujuan DPR ketika presiden ingin pemilihan Kapolri dan Panglima TNI, maka masih sering muncul polemik.

\section{PENUTUP}

Melalui analisis dan pembahasan di atas maka ditarik simpulan sebagai berikut:

1. Secara teoritis dapat dikatakan bahwa telah terjadi pembatasan kekuasaan Presiden dalam rangka mewujudkan pemerintahan konstitusional di Indonesia. Pembatasan kekuasaan Presiden dimaksud, dapat dilihat dari pembatasan kekuasaan Presiden melalui: pertama, pembatasan kewenangan Presiden dalam mengangkat pejabat-pejabat negara dan pembatasan di bidang perundangundangan. Kedua, Pembatasan kekuasaan Presiden dalam hubungannya dengan kekuasaan legislatif, misalnya hubungan fungsional Presiden dengan DPR dalam hal fungsi pengawasan yang dijalankan DPR, kewenangan MPR untuk memberhentikan Presiden dalam masa jabatannya, dan pengawasan DPD terhadap Presiden. Ketiga, pembatasan kekuasaan Presiden dalam hubungannya

46 Hendra Wahanu Prabandani, Batasan Konstitusional Kekuasaan Eksekutif Presiden: Constitutional Limits Of The Presidential Executive Power, h. 17.

${ }^{47}$ Erwin Chemerinsky dikutip Hendra Wahanu Prabandani, Batasan Konstitusional Kekuasaan Eksekutif Presiden: Constitutional Limits Of The Presidential Executive Power, h. 275. 
dengan kekuasaan yudikatif, misalnya kewenangan MK yang terlibat dalam pemberhentian Presiden yang memutus dugaan DPR dari segi yuridis, dan kewenangan MA yang dapat menguji peraturan perundang-undangan yang dibuat Presiden terhadap Undang-Undang.

2. Pembatasan isi kekusaan Presiden mempunyai pengaruh terhadap praktik ketatanegaraan yaitu dengan semakin memperkuat sistem pemerintahan presidensial, dan pada praktiknya terjadi hubungan saling mengawasi dan mengimbangi antar cabang kekuasaan legislatif, eksekutif dan yudikatif.

3. Sistem presidensial yang dianut oleh Indonesia idelanya memberikan kekuasaan yang luas bagi presiden untuk melaksakan tugas-tugas eksekutifnya. Kekuasaan tersebut tidak dapat dibatasi atau dikurangi tanpa alasan yang bersifat konstitusional. Namun demikian, kekuasaan yang besar tersebut juga tidak dapat digunakan secara semena-mena untuk kepentingan pribadinya. Dua batasan konstitusional yang dapat dijadikan landasan yang dapat dijadikan alasan untuk membatasi kekuasaan eksekutif presiden antara lain adalah batasan hak prerogatif dan prinsip separation of powers.

\section{Daftar Pustaka}

Adnan Buyung dikutip Denny Indrayana, Indonesian Constitutional Reform 1999-2000, An Evaluation of Constitutional Making in Transition, 2009.

Arendt Lijphart dan Giovanni Sartori dikutip Denny Indrayana, Indonesian Constitutional Reform 1999-2000, An Evaluation of Constitutional Making in Transition, h. 279-279.

A.V. Dicey, Introduction to the Study of the Law of the Constitution, Terjemahan oleh Nurhadi, Pengantar Studi Hukum Konstitusi, Bandung, Nusa Media, 2007.

Bagir Manan, Kekuasaan Prerogatif, Makalah yang dipublikasikan di Bandung, 20 Agustus 1998.

Clement Fatovic, Blurring The Lines: The Continuities Between Executive Power And Prerogative, Maryland Law Review, Vol. 73 No. 15, 2013.

Denny Indrayana, Indonesian Constitutional Reform 1999-2000, An Evaluation of Constitutional Making in Transition, Jakarta, Kompas Book Publishing, 2008.

Hendra Wahanu Prabandani, Batasan Konstitusional Kekuasaan Eksekutif Presiden: Constitutional Limits Of The Presidential Executive Power, Jakarta, Jurnal Legislasi, 2015.

Jasmin Farrier, Legislatif Leader dalam The Powers of the Presidency (4th Edition), CQ Press, Los Angeles California, 2013.

Jimly Asshiddiqie, Perkembangan dan Konsolidasi Lembaga Negara Pasca Reformasi, Penerbit Sekretariat Jenderal Mahkamah Konstitusi RI, Jakarata, 2006. 
Struktur Ketatanegaraan Indonesia Setelah Perubahan Keempat UUD Tahun 1945, makalah disampaikan pada Seminar Pembangunan Hukum Nasional VIII yang diselenggarakan oleh Badan Pembinaan Pembangunan Hukum Nasional Departemen Hukum dan HAM pada tanggal 14-18 Juli 2003.

John D. Richard, Separation of Powers: The Canadian Experience, Duquesne Law Review, Vol. 47 No. 731, 2009.

John F. Manning, Separation Of Powers As Ordinary Interpretation, Harvard Law Review, Vol 124 No. 1939, 2011.

Kementerian Pendidikan Nasional RI, Kamus Besar Bahasa Indonesia, Jakarta, Pusat Bahasa, 2012.

M. Elizabeth Magill, The Real Separation in Separation of Powers Law, Virginia Law Review, Vol. 86 No. 1127, h. 1163-1164.

Padmo Wahjono (Editor), Masalah Ketatanegaraan Indonesia Dewasa Ini, Jakarta, Ghalia Indonesia, 1984.

Sri Soemantri Martosoewignjo, Konstitusi Serta Artinya Untuk Negara, Jakarta, Kompas Book Publishing, 2011. 